MANAGERIAL EGONOMICS 


\section{MANAGERIAL EGONOMICS}

\section{PETER J. CURWEN}


(C) Peter J. Curwen 1974

All rights reserved. No part of this publication may be reproduced or transmitted, in any form or by any means, without permission.

\author{
First published 1974 by \\ THE MAGMILLAN PRESS LTD \\ London and Basingstoke \\ Associated companies in New York Dublin \\ Melbourne Fohannesburg and Madras
}

ISBN 978-0-333-15888-3 ISBN 978-1-349-15524-8 (eBook)

DOI 10.1007/978-1-349-15524-8

To my parents

The paperback edition of this book is sold subject to the condition that it shall not, by way of trade or otherwise, be lent, re-sold, hired out, or otherwise circulated without the publisher's prior consent in any form of binding or cover other than that in which it is published and without a similar condition including this condition being imposed on the subsequent purchaser. 


\section{Contents}

INTRODUCTION vii

1 Basic Goncepts in Degision Making 1

2 Introduction to the Theory of the Firm 29

3 Alternative Theories of the Firm 61

4 Priging Behaviour 113

5 Gapital Investment Appraisal 143

6 Foregasting 173

7 Monopoly Poligy 194

INDEX $\quad 241$ 


\section{Introduction}

The teaching of economics has traditionally been regarded as falling within the province of the university sector of higher education. For this reason the great bulk of all material published in this field has been, and is being, written by university staff at a level suitable for undergraduates and postgraduates pursuing single-discipline courses in economics. Over the past few years however there has been a rapid proliferation of courses in the non-university sector which incorporate economics as a compulsory subject. The majority of these courses are in the fields of Business Studies and Management Studies and involve many thousand students. Despite this fact virtually nothing has been published in the field of economics of direct relevance to these courses. The reason for the paucity of material beyond the introductory level is not hard to discern. Staff in the nonuniversity sector are so overburdened with long teaching hours, administration, and course development, that writing is an unwarranted intrusion upon their free time-unwarranted because it would appear that promotion prospects are poorly correlated with academic endeavour.

This book is an attempt to fill some of the most noticeable gaps in the available literature. It is intended for use by students on Higher Diploma courses in Business Studies, Higher Certificate courses in Business Studies, and Diploma courses in Management Studies. It should also provide useful material for Degree students in these two areas. The level is broadly intermediate, i.e. second year undergraduate level, but care has been taken to make the book acceptable to students with no prior formal training in economics, for example students on the Diploma course in Management Studies. This requirement has meant that some topics traditionally discussed in introductory texts reappear in this book. Nevertheless where this occurs, for example in the chapter on the traditional Theory of 
the Firm, the analysis has been extended well beyond the usual bounds of introductory texts. Besides which the author feels, as a result of personal experience, that it is unwise to progress to more advanced concepts purely on the supposition that students have both fully understood, and can still remember, topics discussed in a previous course.

Obviously, in a book of this nature, the author has had to exercise his personal judgement concerning the topics to include, and also concerning the content of individual chapters. Almost all of the material in this book has been used for teaching purposes on the courses mentioned above, and has been well received. The principle with respect to the selection of material has been to exclude anything more likely to put the student off continuing further than to motivate him to continue. In order to cater for students who wish to refer to the original publications upon which the book is based, full reference is made to all source material by way of footnotes. Where relevant a full bibliography is attached at the end of each chapter, and the author hopes that this will save both teachers and students considerable effort in tracing relevant material where they seek a fuller knowledge of specific areas of the text.

The book is in no way intended to be comprehensive. The decision was taken to concentrate on those aspects of microeconomics which are loosely referred to under the general heading of 'Managerial Economics', a term which has come to encompass a multitude of topics and approaches. Essentially the book is about decision making within a modern firm, and two broad approaches are contained in different sections of the book. Firstly reference is made to a body of generalisations applicable to the operations of a firm (for example in the chapter on modern theories of the firm), and secondly there is a discussion of decision rules which are of practical use in decision making (e.g. in the chapter on Investment Appraisal). The author believes that the two approaches are compatible, and also regards it as important that a would-be manager can handle concepts as well as apply pre-ordained criteria to problems.

The author has found it convenient to divide the book into individual sections which can largely be read as independent units, but the main intention is that the book should be seen as 
a cohesive whole. For the most part conceptual matters are dealt with in the earlier chapters, and decision rules are dealt with in the latter part of the book. The book culminates in a chapter on Monopoly Policy which pulls together many of the threads in earlier sections, since obviously a firm can only be judged as acting in, or against, the public interest, in the light of its objectives, cost conditions, pricing policies and so forth.

In summary therefore this book aims to provide students with a relatively non-technical introduction to an important area of economics which has steadily become clouded in obscurity. The author wishes to thank the (for the most part anonymous) referees who have commented on earlier drafts of the book, but wishes to retain full responsibility for all that is contained therein. 